\title{
p53-mediated up-regulation of CD95 is not involved in genotoxic drug-induced apoptosis of human breast tumor cells
}

\author{
María del Carmen Ruiz-Ruiz ${ }^{1}$ and Abelardo López-Rivas ${ }^{\star, 1}$ \\ 1 Instituto de Parasitología y Biomedicina, CSIC, calle Ventanilla 11, 18001 \\ Granada, Spain \\ * Corresponding author: Abelardo López-Rivas, Ph.D., Instituto de Parasitología \\ y Biomedicina, CSIC, calle Ventanilla 11, 18001 Granada, Spain. \\ tel: 34-958-80 51 88; fax: 34-958-20 33 23; e-mail: alrivas1@ipb.csic.es
}

Received 4.11.98; accepted 17.12.98

Edited by S. Nagata

\begin{abstract}
Induction of CD95 (Fas/APO-1) and CD95 ligand during chemotherapeutic treatment may contribute to the death by apoptosis of some tumor cells. In this study, we have analyzed the role of the CD95 system in genotoxic drug-induced death of human breast tumor cells. Incubation of the breast tumor cell lines MCF-7 and EVSA-T with doxorubicin or methotrexate caused apoptosis after $48 \mathrm{~h}$ of treatment. These drugs induced a marked increase in the level of CD95 mRNA and protein in wild-type p53-expressing MCF-7 cells. On the contrary, the breast cancer cell line EVSA-T that expresses high levels of an inactive form of p53, did not up-regulate CD95 upon drug treatment. Elevation of CD95 expression by DNAdamaging drugs was notably blocked in MCF-7 cells expressing the human papillomavirus type $16 \mathrm{E} 6$ protein (E6 cells) which prevented p53 accumulation upon DNA damage. However, E6 cells were still killed by the drugs. Furthermore, the genotoxic drugs did not induce the expression of CD95 ligand in MCF-7 cells at doses that caused apoptosis in these breast tumor cells. Moreover, drug-induced apoptosis of breast tumor cells was not prevented in the presence of either a CD95 antagonistic antibody or a CD95 ligand blocking antibody. We also observed a strong synergism between lower doses of DNA-damaging drugs and CD95 agonistic antibody in the induction of apoptosis in MCF-7 cells. In summary, our data indicate that drug-induced apoptosis of breast tumor cells occurs by a CD95/CD95L-independent mechanism although by elevating the tumor suppressor proteins $p 53$ and CD95, genotoxic drugs may sensitize breast tumor cells to CD95-mediated apoptosis.
\end{abstract}

Keywords: breast; tumor; apoptosis; CD95; CD95L; p53; genotoxic drugs

Abbreviations: TNF/NGF, tumor necrosis factor/nerve growth factor; ICE, interleukin-1 $\beta$-converting enzyme; PBS, phosphatebuffered saline

\section{Introduction}

Genotoxic drugs have been widely used in antitumor therapy and have been shown to activate a death program by apoptosis in many cells. ${ }^{1}$ Most DNA-damaging treatments induce the accumulation of the tumor suppressor protein p53 which modulates the cellular response to DNA damage by inducing cell cycle arrests and, in some instances, apoptosis. $^{2-4}$ Recent reports indicate that in some tumor cells DNA damage-induced apoptosis may be mediated through the CD95/CD95 ligand system by the induction of both proteins in treated cells. ${ }^{5,6}$

The CD95 (Fas/APO-1) receptor, a member of the tumor necrosis factor/nerve growth factor (TNF/NGF) receptor family $^{7,8}$ is a very potent inducer of apoptosis in the immune system. The specific ligand for CD95 (CD95L) has been identified as a type II integral membrane protein homologous to $\mathrm{TNF}^{9}$ although it can also be present in a soluble form. ${ }^{10}$ Defects in the genes coding for either CD95 or its ligand have been demonstrated to be responsible for certain lymphoproliferative diseases in mice and humans. ${ }^{11,12}$ Outside the immune system the CD95 antigen is also expressed in many non-transformed cells including mammary epithelial cells. ${ }^{13}$ In contrast, breast tumor cells express low levels of CD95 mRNA and protein and are usually not killed by anti-CD95 antibodies. ${ }^{14}$ Therefore, treatments that can either induce the expression of both CD95 and CD95 ligand or sensitize tumor cells to cell death upon ligation of CD95 receptors in their membranes could consequently be of therapeutical importance. In this respect, recent data from several groups have shown that chemotherapeutic drugs and interferon- $\gamma$ enhance the sensitivity of some tumor cells to either CD95 antibodies or CD95 ligand. ${ }^{14-16}$ Recently, a correlation has been found between expression of wild-type p53 and induction of CD95 receptor after $\gamma$-irradiation of different tumor cell lines. ${ }^{17}$ Furthermore, it has been suggested that a p53responsive element exists in the promoter region of the CD95 gene. ${ }^{18}$

The above data prompted us to investigate the effect of DNA-damaging drugs on the viability of different breast tumor cell lines and to analyze the expression of CD95 and CD95 ligand after DNA damage. We have also determined the role of $\mathrm{p53}$ in the regulation of CD95 expression by chemotherapeutic drugs in breast tumor cells. We show here that the accumulation of p53 in drug-treated breast tumor cells is required for DNA damage-induced CD95 expression and that overexpression of p53 is sufficient to increase the cellular levels of this death receptor in breast tumor cells. However, CD95 ligand is not induced by DNAdamaging drugs. Furthermore, up-regulation of CD95 expression is not required for drug-induced cell death in 
breast tumor cells. Despite the lack of involvement of the CD95 system in the killing of breast tumor cells by genotoxic agents, these treatments enhance the sensitivity of tumor cells to ligation of the CD95 receptor in the cell membrane.

\section{Results}

\section{Induction of apoptosis by genotoxic drugs in breast tumor cell lines}

In this report we have studied the effect of two genotoxic drugs, methotrexate and doxorubicin, on the viability of breast tumor cells in culture. The results shown in Figure 1a indicate that both drugs killed the breast tumor MCF-7 and EVSA-T cell lines as determined by analyzing the loss of cells from the culture after $48 \mathrm{~h}$ of treatment. Similar results were obtained in two other breast tumor cell lines (T47D and MDA-MB-231, results not shown). The genotoxic drugs caused a significant loss of cell viability in both cell lines, although doxorubicin was always more effective than methotrexate (Figure 1a).

MCF-7 cells have been reported to lack caspase-3 activity ${ }^{19}$ (our unpublished results). This defect resulted in a diminished capacity to activate DNA fragmentation during apoptotic cell death ${ }^{19}$ (our unpublished results). To determine if the cell death observed in MCF-7 and EVSA$T$ cells corresponded to apoptosis, we analyzed the exposure of phosphatidylserine (PS) in the extracellular side of the plasma membrane. Following treatment with genotoxic drugs there was an increase in exposure of PS in both cell lines (Figure 1b). However, despite significant cell loss (Figure 1a), PS exposure was markedly reduced in MCF-7 cells (Figure 1b) compared to EVSA-T cells which express caspase-3 (not shown). This is not surprising as recent results have demonstrated that caspase- 3 is involved in the mechanism leading to PS exposure in apoptotic cells. ${ }^{20}$ To further confirm that both cell lines were dying by apoptosis, we determined the proteolytic degradation of the caspases substrate poly(ADP-ribose)polymerase (PARP). As shown in Figure 1c, PARP was cleaved to a similar extent in both MCF-7 and EVSA-T cells upon treatment, generating the $29 \mathrm{kDa}$ fragment specific of caspase action.

\section{Genotoxic drugs induce the expression of CD95 in breast tumor cells through a p53-dependent mechanism}

To understand the mechanism underlying the death of breast cancer cells treated with DNA-damaging agents, we initially studied CD95 expression in MCF-7 and EVSA-T cells. We used methotrexate and doxorubicin at doses apoptosisinducing (Figure 1) and $\gamma$-irradiation. All DNA-damaging treatments clearly increased the number of CD95-expressing MCF-7 cells (Figure 2a) after 24-48 h of culture. In contrast, these treatments failed to induce the expression of CD95 in EVSA-T cells (Figure 2a). To exclude the possibility that the drug-induced increase in binding sites for anti-CD95 antibody represented merely an enhanced exposure of CD95 protein in the cell surface of MCF-7 cells, we determined the cellular $\boldsymbol{a}$

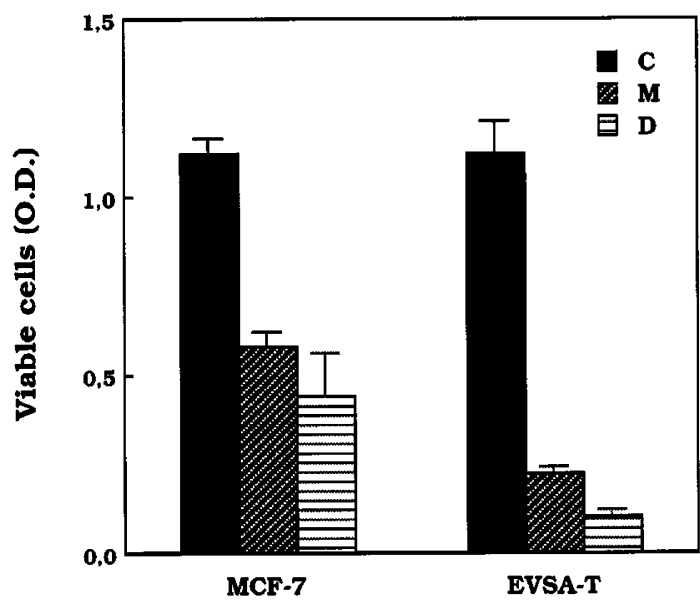

b

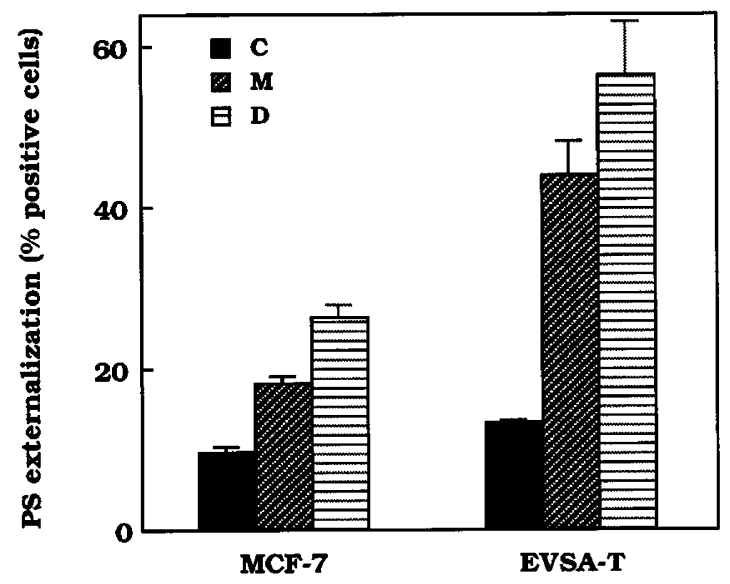

c

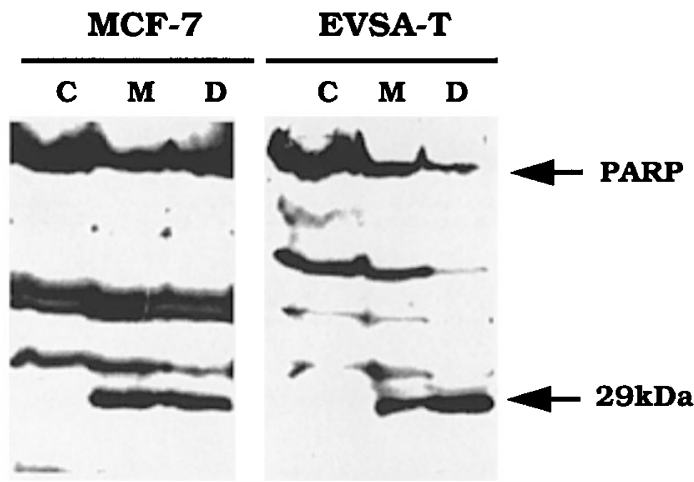

Figure 1 Induction of apoptosis by genotoxic drugs in breast tumor cells. MCF-7 and EVSA-T cells were incubated for $48 \mathrm{~h}$ without (C) or with $100 \mu \mathrm{g} / \mathrm{ml}$ methotrexate (M) or $500 \mathrm{ng} / \mathrm{ml}$ doxorubicin (D). Loss of cell viability and apoptosis were assessed by the crystal violet method (a) and PS externalization (b). Error bars represent SD from at least two independent experiments. (c) Caspase-mediated PARP cleavage was determined by Western blot. The $29 \mathrm{kDa}$ fragment of PARP cleavage is shown 
a
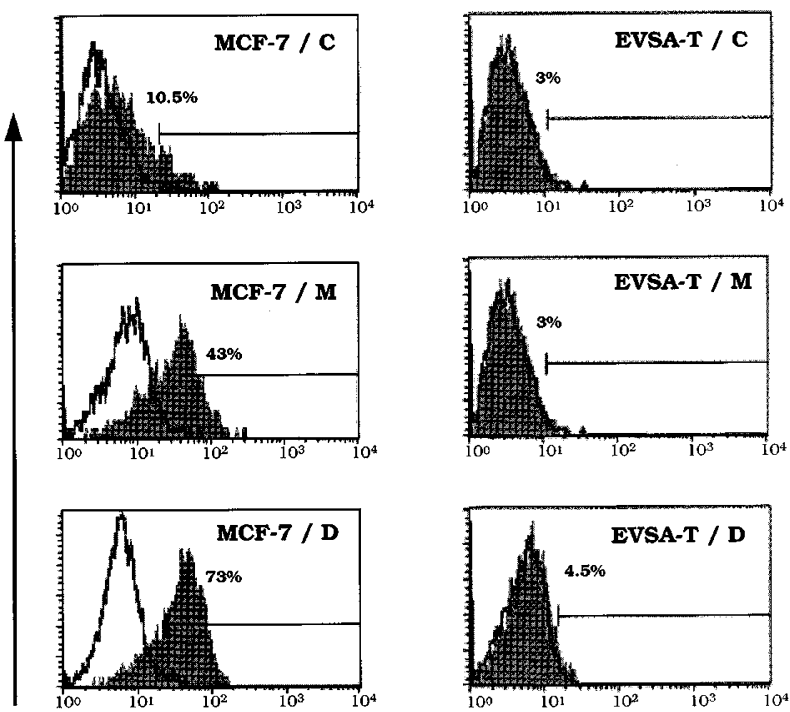

兽

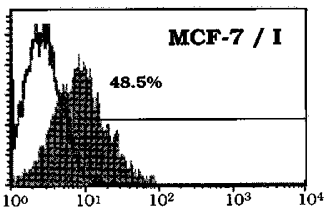

FAS EXPRESSION

b

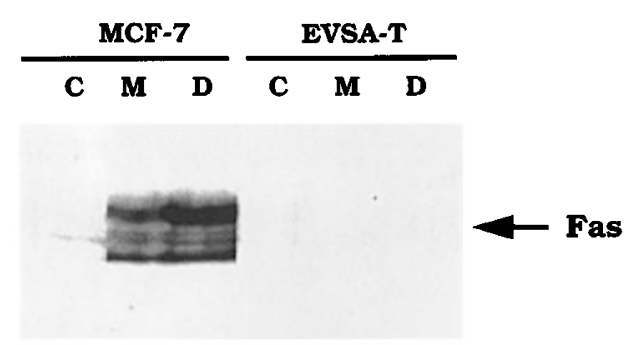

c

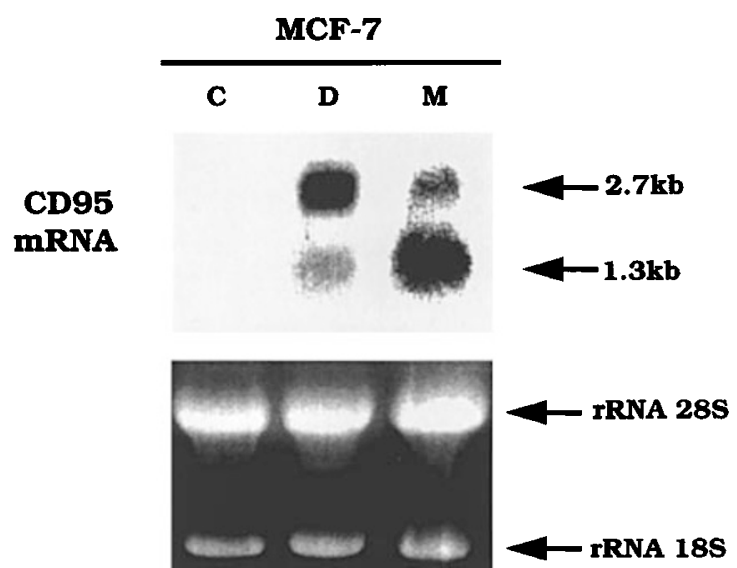

Figure 2 Upregulation of CD95 in MCF-7 cells upon genotoxic treatments. (a) CD95 receptor expression was determined by flow cytometry in MCF-7 and EVSA-T cells incubated in the absence (C) or in the presence of $100 \mu \mathrm{g} / \mathrm{ml}$ methotrexate (M) for $48 \mathrm{~h}, 500 \mathrm{ng} / \mathrm{ml}$ doxorubicin (D) for $24 \mathrm{~h}$, or $24 \mathrm{~h}$ after $6 \mathrm{~Gy}$ $\gamma$-irradiation (I). (b) Cells were treated either with $100 \mu \mathrm{g} / \mathrm{ml}$ methotrexate for level of CD95 protein by Western blot analysis. Results shown in Figure $2 \mathrm{~b}$ demonstrate that both methotrexate and doxorubicin up-regulated the expression of CD95 protein in MCF-7 cells. the same treatments were not able to induce CD95 protein in EVSA-T cells.

To further investigate the up-regulation of CD95 by chemotherapeutic drugs we analyzed by Northern blot the expression of CD95 mRNA in MCF-7 cells treated with methotrexate or doxorubicin. As shown in Figure 2c, MCF-7 cells expressed low levels of CD95 mRNA in consonance with the protein data (Figure $2 \mathrm{~b}$ ), as previously reported. ${ }^{14}$ However, following genotoxic treatment there was a marked accumulation of two mRNA transcripts of 2.7 and $1.9 \mathrm{~kb}$ in MCF-7 cells. These two mRNAs have been already observed in other cell types and are probably generated by an alternative use of two different poly $(A)$ addition signals. $^{7}$

It has been proposed that the tumor suppressor protein p53 which participates in the cellular response to DNA damage, could be involved in the up-regulation of the expression of several apoptosis-related genes. ${ }^{21}$ Furthermore, it was recently demonstrated that CD95 expression can be up-regulated in hepatoma cells in a p53-dependent manner following treatment with DNA-damaging agents. ${ }^{6}$ To determine the role of p53 in CD95 expression in breast tumor cells, we initially studied the p53 response in different breast cancer cell lines. Among the various cell lines analyzed (MCF-7, T47D, EVSA-T and MDA-MB-231, unpublished observations), in this report we present the results with two cell lines, MCF-7 and EVSA-T, which, in terms of p53 activity, represented two opposite examples. In these two cell lines we analyzed the effect of chemotherapeutic drugs on the accumulation of p53 and the expression of the proteins WAF1/p21 and MDM-2 whose genes are regulated at the transcriptional level by p53. ${ }^{21}$ Although p53-independent mechanisms have been described for the up-regulation of WAF1/p21 and MDM-2 genes in response to DNA damage, ${ }^{22,23}$ their expression frequently represents an indicator of p53 activity. Figure $3 a$ shows that in MCF-7 cells, p53 level was low in untreated cultures and there was a marked accumulation of p53 after treatment with drugs. In contrast, untreated EVSA-T cells showed a greatly elevated level of p53 and there was only a small increase in p53 after treatments (Figure 3a). An elevated level of p53 is frequently indicative of reduced degradation by cellular proteases and has been observed in tumor cells with mutated p53. ${ }^{24}$ These mutant p53 proteins are frequently devoid of transcriptional activity. ${ }^{25}$ The above results with the EVSA-T cell line suggest that these cells might express a mutated and inactive form of p53. To determine whether EVSA-T cells contain an inactive p53 we compared the expression of WAF/p21 and MDM-2 proteins in MCF-7 and EVSA-T cells after

$24 \mathrm{~h}$ or with $500 \mathrm{ng} / \mathrm{ml}$ doxorubicin for $15 \mathrm{~h}$ and CD95 protein levels were analyzed by Western blotting. (c) MCF-7 cells were treated either with $100 \mu \mathrm{g} /$ $\mathrm{ml}$ methotrexate for $12 \mathrm{~h}$ or with $500 \mathrm{ng} / \mathrm{ml}$ doxorubicin for $8 \mathrm{~h}$ and CD95 mRNA was detected by Northern blot analysis 
treatment with either methotrexate or doxorubicin. Figure $3 \mathrm{~b}$ shows that both WAF/p21 and MDM-2 proteins were upregulated in MCF-7 cells following incubation with drugs. In contrast, EVSA-T cells failed to express these proteins in response to chemotherapeutic agents (Figure $3 b$ ). These results suggest that EVSA-T cells might contain an inactive p53, perhaps explaining why these cells failed to express CD95 following DNA damage (Figure $2 a$ and b). These results also indicate that drug-induced apoptosis was independent of the CD95 system in EVSA-T cells.

In order to demonstrate that p53 accumulation was required for the elevation of CD95 expression in drugtreated cells, we generated by transfection MCF-7 cells expressing the human papillomavirus type 16 E6 protein. Overexpression of E6 protein has been shown to induce the degradation of p53 and thus prevent the accumulation of p53 in cells treated with DNA damaging agents. ${ }^{26}$ Several clones were analyzed for the accumulation of p53 following treatment with doxorubicin. Figure 4 shows the results obtained with two clones of MCF-7 cells transfected with E6 cDNA (E6 B3 and E6 C1) and one clone of cells transfected with vector DNA (pCMV-neo). As shown in Figure $4 \mathrm{a}$, the clones transfected with E6 exhibited a markedly reduced response to doxorubicin in the accumulation of p53 when compared to the pCMV-neo cells. These results suggest that $\mathrm{E} 6$ cells represent a suitable model to analyze the role of p53 in CD95 expression. To this end, we first determined the expression of WAF1/p21 protein, whose gene is regulated at the transcriptional level by p53. Results presented in Figure $4 b$ indicate that in pCMV-neo cells, WAF1/p21 was up-regulated following treatment with doxorubicin. On the contrary, E6 clones failed to elevate WAF1/p21 protein upon drug treatment (Figure 4b). The same pattern of expression was obtained when CD95 protein was analyzed (Figure $4 \mathrm{~b}$ ), which demonstrated that induction of CD95 protein by DNA-damaging drugs required the presence of elevated levels of p53.

\section{Temperature sensitive p53-expressing breast tumor cells up-regulated CD95 expression upon shift to $32^{\circ} \mathrm{C}$}

The above results indicated that p53 accumulation is a necessary event in the up-regulation of death receptor expression in breast tumor cells upon treatment with genotoxic drugs. To further demonstrate the importance of p53 activity in regulating CD95 expression in breast tumor cells, we tried to generate MCF-7 cells stably overexpressing a mouse mutant temperature-sensitive p53 (Val135). ${ }^{27}$ Transfection of temperature-sensitive p53 into cells has been used to generate an inducible p53 response. ${ }^{27-30}$ Shifting the cells from the restrictive temperature $\left(37-38^{\circ} \mathrm{C}\right)$ at which the protein acquires an inactive conformation to low temperature $\left(32^{\circ}\right)$ renders an active wild-type conformation. ${ }^{27}$ This approach has made it feasible to demonstrate the involvement of p53 in different cellular processes. ${ }^{27-30}$ Several MCF-7 clones which constitutively expressed mouse $\mathrm{p} 53^{\text {ts }}$ were obtained by transfection. From these clones we chose one that expresses mouse p53 (Figure 5a) at a level comparable to that of endogenous p53 achieved in MCF-7

$\boldsymbol{a}$

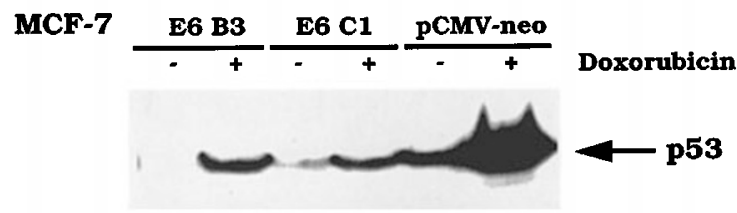

$\boldsymbol{b}$
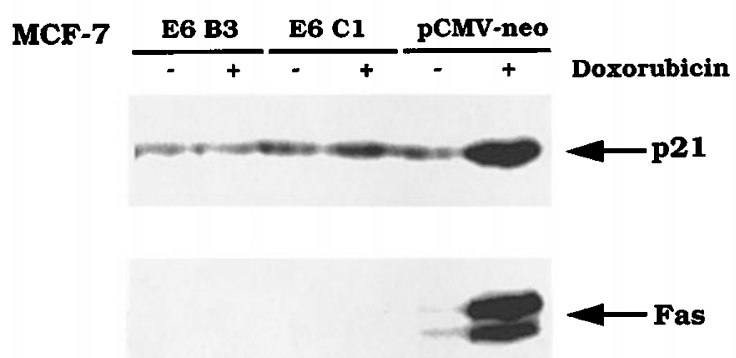

Figure 4 Human papillomavirus type $16 \mathrm{E} 6$ protein inhibits accumulation of p53 and up-regulation of CD95 upon genotoxic treatment in MCF-7 cells. MCF7 cells were stably transfected either with an empty vector (pCMV-neo) or with a plasmid encoding E6 protein (pCMV16-E6). Protein levels of p53 (a) and WAF1/p21 and CD95 (b) were analyzed by Western blotting in E6 and pCMVneo clones after treatment with or without $500 \mathrm{ng} / \mathrm{ml}$ doxorubicin for $15 \mathrm{~h}$
Figure 3 Accumulation of p53 protein and expression of WAF1/p21 and MDM-2 in breast tumor cells. Protein levels of p53 (a), p21 and mdm-2 (b) were determined by Western blotting in MCF-7 and EVSA-T cells after incubation in the absence (C) or in the presence of $100 \mu \mathrm{g} / \mathrm{ml}$ methotrexate (M) for $15 \mathrm{~h}$ or $500 \mathrm{ng} / \mathrm{ml}$ doxorubicin (D) for $10 \mathrm{~h}$ 
cells after drug treatment (Figure 3a). To elucidate the role of p53 in the induction of CD95, we first determined whether culturing $p 53^{\text {ts }}$ cells at $32^{\circ} \mathrm{C}$ was sufficient to up-regulate the expression of WAF1/p21 protein. Results shown in Figure $5 b$ demonstrate that whereas control (puro) cells expressed similar amounts of WAF1/p21 protein at both temperatures, p53 ${ }^{\text {ts }}$ cells clearly up-regulated WAF1/p21 levels at $32^{\circ} \mathrm{C}$. These results indicate that mutant p53 (Val135) was acting as wild-type p53 at $32^{\circ} \mathrm{C}$ in MCF-7 cells and allow us to address whether the accumulated p53 in drug-treated cells was sufficient to elevate CD95 receptor expression in breast tumor cells. Figure 5b shows that control (puro) cells did not express CD95 protein at either temperature. Interestingly, CD95 protein level which was low in $\mathrm{p} 3^{\text {ts }}$ cells maintained at $37^{\circ} \mathrm{C}$, was markedly increased after incubation for 3 days at $32^{\circ} \mathrm{C}$. Similar results were obtained when CD95 expression in the cell surface was analyzed by flow cytometry (not shown).

\section{CD95/CD95 ligand interaction does not mediate genotoxic drug-induced apoptosis in MCF-7 breast tumor cells}

It was recently demonstrated that the activation of the CD95/ CD95L system by DNA-damaging drugs plays a role in the apoptotic death of certain tumor cells..$^{5,6,31}$ In addition, it was shown that ceramide, which accumulates in response to stress, mediates the up-regulation of CD95 ligand expression and apoptosis observed following drug addition or gamma irradiation. ${ }^{32}$ However, more recent data has indicated that

a.

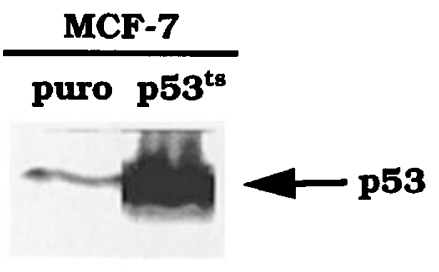

b

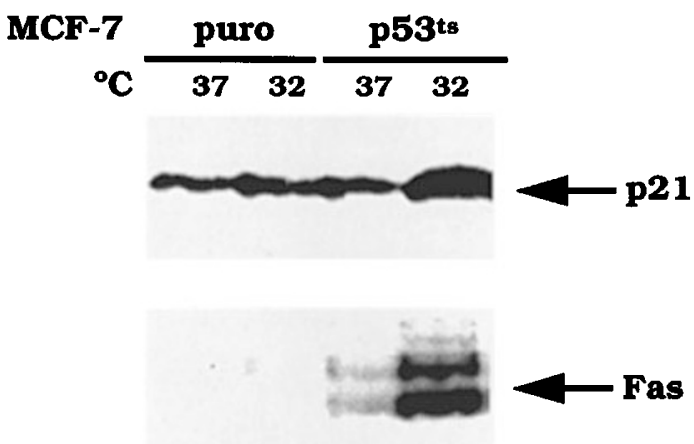

Figure 5 Overexpression of p53 induces upregulation of CD95 in MCF-7 cells. MCF-7 cells were stably transfected either with a temperature-sensitive mutant p53 or with an empty vector as indicated in Materials and Methods. (a) Basal levels of p53 protein in both types of cells determined by Western blotting. (b) Cells were incubated at the permissive $\left(32^{\circ} \mathrm{C}\right)$ or non-permissive $\left(37^{\circ} \mathrm{C}\right)$ temperature for 3 days and the levels of $\mathrm{p} 21$ and CD95 proteins were determined by Western blotting not all stress stimuli use the same cell death pathways. ${ }^{33}$ It was shown that UV, gamma irradiation, and anisomycinstimulated C-Jun N-terminal kinase activity and induced CD95 ligand expression in leukemic cells. Nevertheless, only anisomycin-induced apoptosis was dependent on CD95/ CD95 ligand interactions. ${ }^{33}$ To assess the importance of the CD95/CD95L system in genotoxic drug-induced apoptosis of breast tumor cells, we first evaluated the sensitivity of E6 MCF-7 cells to drug-induced apoptosis. We have shown previously that these cells did not up-regulate CD95 expression in response to doxorubicin treatment (Figure 4b). Interestingly, E6 cells were still sensitive to doxorubicininduced apoptosis (Figure 6) which suggested that the mechanism underlying apoptosis upon DNA damage did not involve the up-regulation of CD95. Similar results were obtained with methotrexate (not shown).

To further investigate the role of the CD95/CD95L system in drug-induced apoptosis in MCF-7 cells we carried out the experiments in the presence of either a CD95 antagonistic antibody or a CD95L blocking antibody. As a control of cells which undergo CD95L-mediated apoptosis we used J-HM1-2.2 Jurkat leukemic cells expressing the human muscarinic acetylcholine type 1 (HM1) receptor. These cells up-regulate FasL expression and undergo apoptosis upon activation of the muscarinic receptor with the agonist carbachol. ${ }^{34}$ Results shown in Figure 7c indicate that carbachol-induced apoptosis required the formation of a CD95/CD95 ligand complex as it could be blocked by either an antagonistic CD95 Ab (DX2) or a CD95 ligand blocking $A b$ (NOK-1). On the contrary, genotoxic drug-induced apoptosis of breast tumor cells was not prevented by blocking CD95/CD95 ligand interactions with antagonistic CD95 Ab or CD95 ligand Ab (Figure $7 \mathrm{a}$ and b). Furthermore, genotoxic drugs did not induce the expression of CD95 ligand in breast tumor cells (Figure 8), as determined by Western blot analysis with the

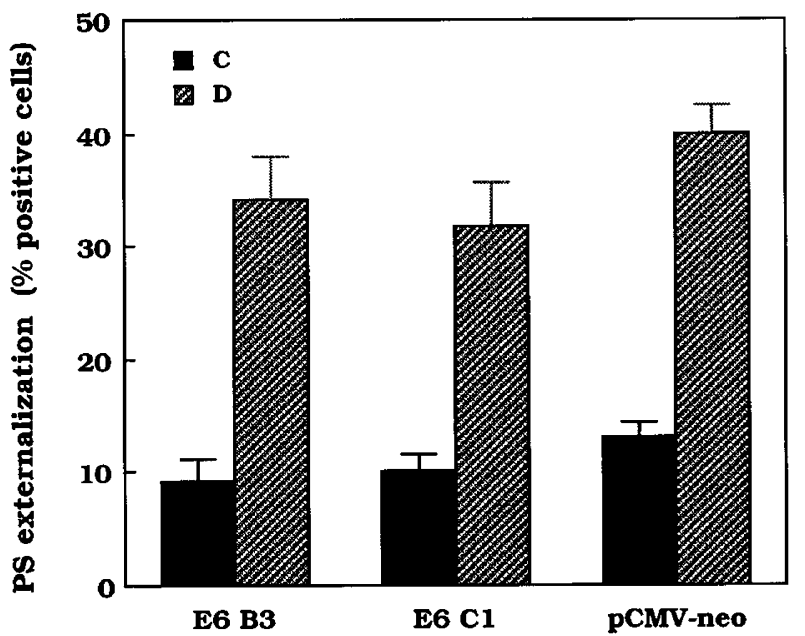

Figure 6 MCF-7 cells transfected with the human papillomavirus type 16 E6 cDNA remains sensitive to genotoxic drug-induced apoptosis. E6 and pCMVneo clones were incubated without $(C)$ or with $500 \mathrm{ng} / \mathrm{ml}$ doxorubicin (D) for $48 \mathrm{~h}$. PS externalization in the population was determined by flow cytometry. Errors bars represent S.D. from at least three independent experiments 
$\boldsymbol{a}$

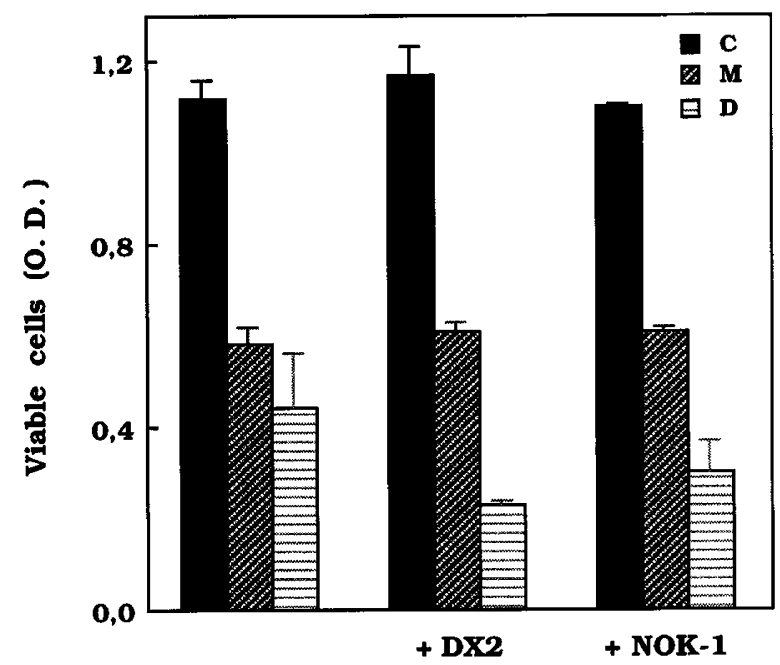

$\boldsymbol{b}$

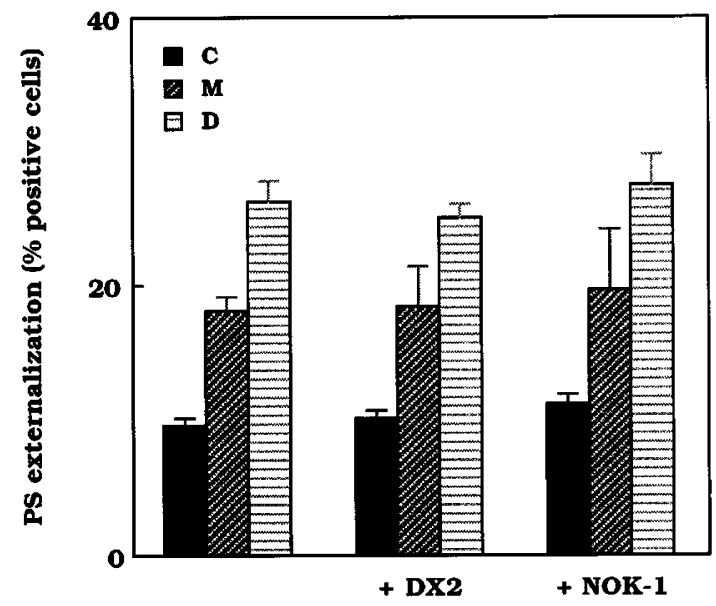

c

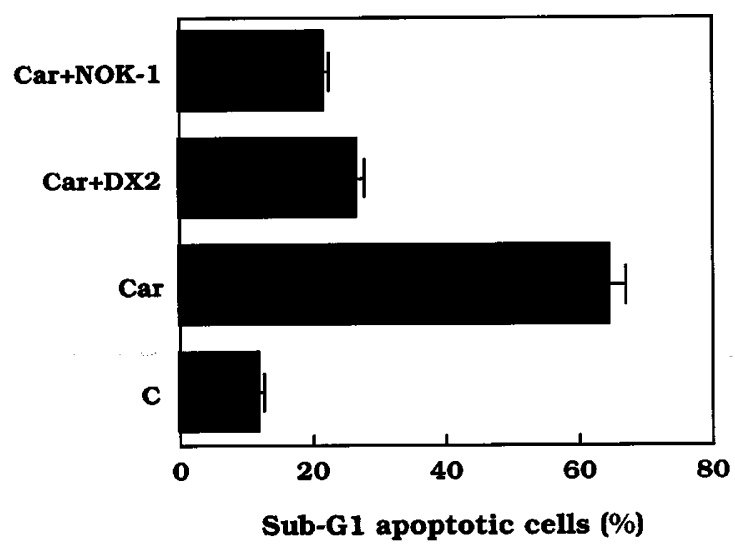

Figure 7 Induction of apoptosis by genotoxic drugs in MCF-7 breast tumor cells is not inhibited by blocking the CD95/CD95L interaction. (a) Cell viability and (b) PS externalization were determined after $48 \mathrm{~h}$ treatment of MCF-7 cells without (C) or with $100 \mu \mathrm{g} / \mathrm{ml}$ methotrexate (M) or $500 \mathrm{ng} / \mathrm{ml}$ doxorubicin (D) in the absence or in the presence of antagonistic Fas mAb (+DX2) or Fas ligand
CD95L antibody Q-20. By using the same CD95L antibody we were able to detect CD95L up-regulation in J-HM1-2.2 Jurkat cells treated with carbachol (Figure 8). Altogether, these results demonstrated that in MCF-7 cells chemotherapeutic drug-induced apoptosis occurred by a CD95/ CD95L-independent mechanism.

\section{Agonistic CD95 antibody and lower concentrations of DNA-damaging drugs synergistically induce apoptosis in breast tumor cells}

Despite the lack of CD95/CD95L involvement in genotoxic drug-induced apoptosis of breast tumor cells, we were interested in knowing whether lower, non-apoptotic doses of genotoxic drugs could up-regulate CD95 in the cell membrane of MCF-7 cells and render these cells susceptible to CD95 ligation-mediated apoptosis. Treatment of cells from the breast tumor cell line MCF-7 with lower concentrations of either methotrexate or doxorubicin still induced CD95 expression in the cell membrane (Figure 9a). The drugs at the doses used in these experiments, did not cause apoptosis in the short-term (Figure 9b), although they did activate this cell death program after prolonged incubation (not shown). However, when the cells were incubated with the drugs in the presence of agonistic CD95 antibody $\mathrm{CH}-11$, a marked synergism was found in the induction of cell death (Figure 9b).

\section{Discussion}

Several studies have indicated that the CD95/CD95L system is involved in the mechanism of genotoxic drug-induced apoptosis in different tumor cells. ${ }^{5,6,31}$ Furthermore, it was recently demonstrated in hepatoma cells that apoptotic cell death induced by antitumor drugs involves the regulation of the CD95/CD95 ligand system and is dependent on wild-type p53. ${ }^{6}$ More recently, it was shown that ceramide, which

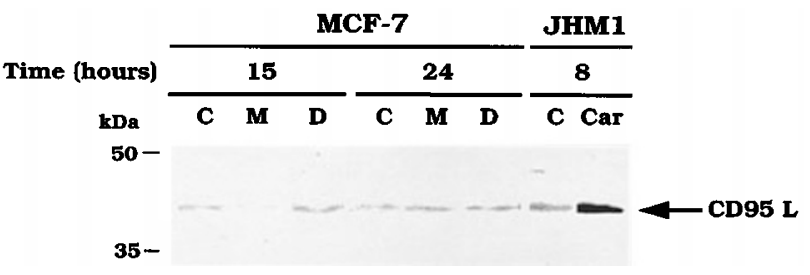

Figure 8 CD95L is not induced by genotoxic drugs in MCF-7 breast tumor cells. Fas ligand expression was determined by Western blot analysis in MCF7 cells following treatment without (C) or with $100 \mu \mathrm{g} / \mathrm{ml}$ methotrexate (M) or $500 \mathrm{ng} / \mathrm{ml}$ doxorubicin (D) for 15 and $24 \mathrm{~h}$. As a control, Fas ligand expression was also determined in J-HM1-2.2 cells upon treatment without (C) or with $500 \mu \mathrm{M}$ carbachol (Car)

mAb (+NOK-1). (c) Cultures of J-HM1-2.2 Jurkat cells were incubated for $8 \mathrm{~h}$ without (C) or with $500 \mu \mathrm{M}$ carbachol in the absence (Car) or presence of antagonistic Fas mAb (Car+DX2) or Fas ligand mAb (Car+NOK-1) and hypodiploid apoptotic cells were determined by flow cytometry. Error bars represent S.D. from at least two independent experiments 
$\boldsymbol{a}$

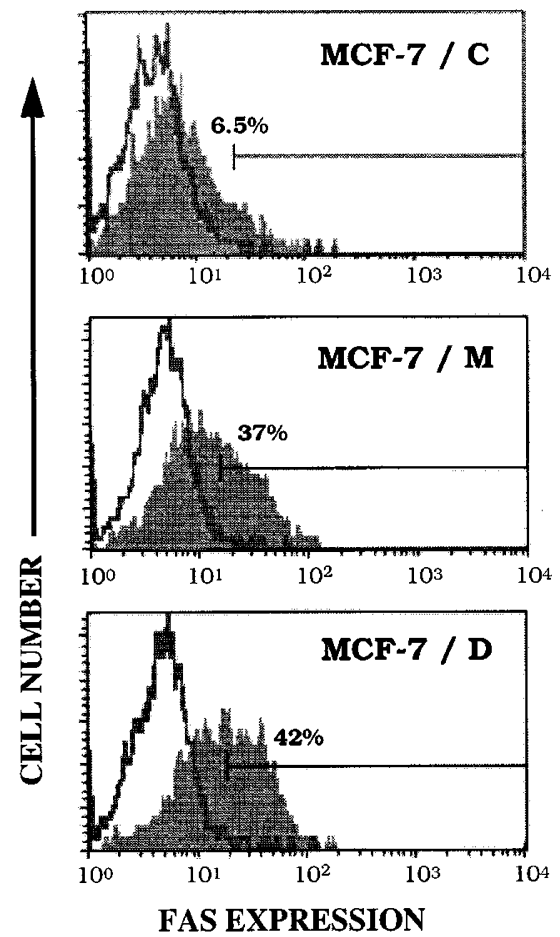

$\boldsymbol{b}$

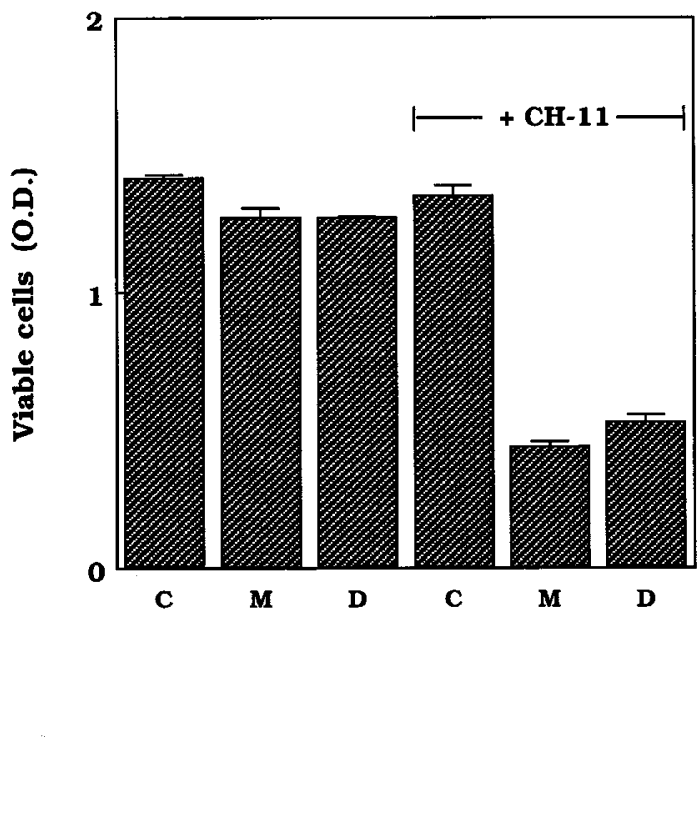

Figure 9 Synergistic effect of CD95 mAb and lower doses of genotoxic drugs in the induction of apoptosis in MCF-7 cells. (a) CD95 expression was analyzed by flow cytometry in MCF-7 cells after incubation for $24 \mathrm{~h}$ without (C) or with $10 \mu \mathrm{g} / \mathrm{ml}$ methotrexate (M) or $100 \mathrm{ng} / \mathrm{ml}$ doxorubicin (D). (b) MCF-7 cells were incubated without (C) or with $10 \mu \mathrm{g} / \mathrm{ml}$ methotrexate (M) or $100 \mathrm{ng} / \mathrm{ml}$ doxorubicin (D) in the presence or in the absence of $500 \mathrm{ng} / \mathrm{ml} \mathrm{CD} 95 \mathrm{mAb} \mathrm{CH} 11$. After $48 \mathrm{~h}, \mathrm{cell}$ viability was assessed by crystal violet staining. Error bars represent S.D. from two independent experiments

accumulates in response to stress, mediates the upregulation of CD95 ligand expression and apoptosis observed following drug addition or gamma irradiation. ${ }^{32}$ Our results in breast tumor cells are in agreement with the results obtained in hepatic carcinomas in the sense that wildtype p53 is necessary for drug-induced up-regulation of the CD95 receptor. ${ }^{6}$ However, in contrast to the hepatoma system, we did not detect CD95 ligand in breast tumor cells treated with DNA-damaging drugs which induce CD95 expression and apoptosis. Our results also demonstrate that preventing p53 accumulation and CD95 expression with the HPV16-E6 protein does not block drug-induced apoptosis in MCF-7 breast tumor cells. Furthermore, blocking the interaction between CD95 and CD95L with specific antibodies does not prevent chemotherapeutic drug-induced apoptosis in breast tumor cells. On the other hand, our data indicate that EVSA-T cells do not express CD95 receptor and its expression is not up-regulated by genotoxic drugs. However, these cells are sensitive to chemotherapeutic drug-induced apoptosis. Altogether, these data suggest that in the breast tumor cell lines studied, DNA damage-induced apoptosis does not require up-regulation of the CD95/CD95 ligand system. Moreover, after analyzing different breast cancer cell lines we observed no direct correlation between drug-induced cell death and p53 activity (not shown), suggesting that p53-independent mechanisms of apoptosis may be operating in breast carcinomas, as recently reported in human breast tumor xenografts. ${ }^{35}$ Similar findings have been reported in other tumor cells. ${ }^{36,37}$

In our experiments we observed the cleavage of PARP in drug-treated cells. These results suggest that the activation of caspases may be the mechanism underlying genotoxic drug-induced apoptosis of breast tumor cells. It is interesting that drug-induced PARP cleavage is observed in MCF-7 cells which do not express caspase-3 due to gene deletion. ${ }^{19}$ However, recently published data indicate that other caspases may also play a role in the degradation of nuclear substrates. ${ }^{20,38}$ The mechanism by which genotoxic stress leads to activation of caspases and apoptosis is not clear. Nevertheless, some clues have been provided by recent work showing the up-regulation of caspases genes in human leukemic cells and colon carcinoma cells following genotoxic treatment. ${ }^{39}$ In this report, the increased expression of caspases preceded the appearance of apoptotic characteristics. ${ }^{39}$ Furthermore, other studies have provided evidence for a p53-independent up-regulation of caspases genes and apoptosis by chemotherapeutic drugs, through the induction of interferon-responsive transcriptional activator, IRF-1. ${ }^{40,41}$ Further work is requried to elucidate the mechanisms regulating the activation of caspases in breast tumor cells by chemotherapeutic treatments.

Synergistic action on apoptosis between DNA-damaging drugs and CD95 signaling has been previously observed 
in different tumor cells, ${ }^{15,16}$ although the mechanisms underlying these co-operative effects are not completely understood. Breast tumor cells express low levels of CD95 antigen and therefore are not killed by CD95 antibodies. ${ }^{14}$ The data herein indicate that DNA-damaging drugs sensitize breast tumor cells to CD95-mediated apoptosis. Furthermore, we provide evidence indicating that these drugs induce the expression of CD95 receptor in breast tumor cells, which may explain the strong co-operative effect found between chemotherapeutic drugs and CD95 antibody in the killing of these cells by apoptosis. However, at present we can not exclude the possibility that other signals downstream of the ligation of CD95 receptor can also be facilitated by drug exposure. In this respect, it should be mentioned that breast tumor cells are sensitized to CD95-mediated apoptosis after treatment with interferon- $\gamma .^{14}$ Although the mechanism of this sensitization does not involve an increase in CD95 expression, the level of interleukin- $1 \beta$-converting enzyme (ICE) is enhanced in cells incubated with interferon- $\gamma .^{14}$ Our data suggest that a combined treatment with factors such as interferon- $\gamma$, which induces the expression of enzymes of the cell death machinery used by the CD95/ CD95 ligand system, ${ }^{14}$ and low doses of DNA-damaging drugs, which upregulate CD95 receptor in the membrane of breast tumor cells (this report), may be important in the elimination of the tumor cells by CD95 ligand-expressing cells, namely activated cytotoxic $T$ lymphocytes which infiltrate the tumor. ${ }^{42}$

The regulation of CD95 expression by p53 has been analyzed in several cell models. ${ }^{6,18,43}$ Recently, a correlation was found between expression of CD95 after $\gamma$ irradiation and wild-type p53 activity in different tumor cell lines, including breast cancer cells. ${ }^{17}$ However, direct demonstration that drug-induced elevation of CD95 receptor is dependent on p53 accumulation has not yet been reported in breast tumor cells. Our results with antitumor drugs in MCF-7 cells transfected with the human papillomavirus type 16 E6 DNA are the first demonstration of the role that DNA-damage-mediated p53 elevation play in regulating CD95 expression in breast tumor cells. Furthermore, these results may at least partially explain the observed relation between clinical outcome after radio- or chemotherapy and p53 activity in breast cancer, ${ }^{44-46}$ despite the fact that the p53-independent apoptosis of these tumor cells has been described upon DNA damage in an animal model. ${ }^{35}$

In this report we have shown that in human breast carcinomas, in the absence of DNA damage, the expression of wild-type p53 alone is sufficient to upregulate CD95 receptor levels in these tumor cells. Transfection of human wild-type p53 in human non-small cell lung carcinoma and erythroleukemia cells has recently been shown to cause a marked accumulation of cell surface CD95. ${ }^{18}$ In erythroleukemia cells regulation of CD95 by p53 takes place at the transcriptional level. ${ }^{18}$ Wild-type p53 is a sequence-specific transactivator for gene promoters containing two copies of the motif $5^{\prime}-\mathrm{PuPu}$ $\operatorname{PuC}(\mathrm{A} / \mathrm{T})(\mathrm{T} / \mathrm{A}) \mathrm{GPyPyPy}-3^{\prime} .{ }^{47}$ This sequence has been found in the promoter region of apoptosis-related genes like bax $^{48}$ and IGF-BP3. ${ }^{49}$ Sequence analysis of the human
CD95 promoter has indicated that a DNA-binding site for p53 is present $1.3 \mathrm{~kb}$ upstream in the $5^{\prime}$-flanking region of this gene,$^{50,51}$ although the functionality of this site has not been demonstrated. We are currently investigating the mechanism of p53-dependent up-regulation of CD95 in breast cancer cells.

\section{Materials and Methods}

\section{Materials}

RPMI 1640 medium and FCS were obtained from GIBCO Europe. Crystal violet, methotrexate and doxorubicin were from Sigma Chemical Co. $\mathrm{CH}-11 \mathrm{mAB}(\mathrm{IgM})$ reacting with $\mathrm{CD} 95$ was from Medical \& Biological Laboratories Co. Antagonistic anti-CD95 DX2 $\mathrm{mAb}\left(\mathrm{IgG}_{1}\right)$ and anti-CD95 ligand NOK-1 mAb (IgG1) were obtained from Pharmingen. Anti-CD95 rabbit polyclonal IgG antibody (C-20) and anti-CD95 ligand rabbit polyclonal IgG antibody (Q-20) were purchased from Santa Cruz Biotechnology, Inc. (Santa Cruz, CA, USA). Rabbit polyclonal antiserum against PARP, anti-FII, was generously provided by Dr. G. de Murcia (Ecole Supérieure de Biotechnologie de Strasbourg, CNRS, France).

\section{Cell lines}

The human breast tumor cell lines MCF-7 and EVSA-T were maintained in culture in RPMI 1640 medium containing 10\% FCS, $1 \mathrm{mM} \mathrm{L-glutamine}$ and gentamycin.

\section{Analysis of cell viability and apoptosis}

Cell viability was determined by the crystal violet method as described. ${ }^{52}$ Cell surface PS was detected by flow cytometry after staining with Annexin-V-FLUOS (Boehringer Mannheim). Hypodiploid apoptotic cells were determined by cytofluorimetric analysis of DNA content after extraction of the degraded DNA from apoptotic cells, following a recently described method. ${ }^{53}$ The genotoxic treatments used were methotrexate, doxorubicin or $\gamma$-irradiation (6 Gy). CD95induced apoptosis was assessed after incubation with CD95 mouse monoclonal IgM antibody $\mathrm{CH}-11$.

\section{Immunoblot detection of PARP}

Cells were detached from the culture flask with RPMI medium containing 3 mM EDTA, washed with phosphate-buffered saline (PBS) and resuspended in $20 \mu \mathrm{l}$ sample buffer $(50 \mathrm{mM}$ Tris- $\mathrm{HCl} \mathrm{pH} \mathrm{6.8,6} \mathrm{M}$ urea, $6 \% 2$-mercaptoethanol, $3 \%$ SDS, $0.003 \%$ bromophenol blue) and sonicated. Proteins were resolved on SDS- $10 \%$ polyacrylamide minigels and transferred onto Immobilon membranes (Millipore). The blot was blocked with $5 \%$ milk powder in PBS/0.1\% Tween 20 (PBS/ Tween) for $1 \mathrm{~h}$, washed with PBS/Tween, and incubated with antiserum anti-FII $(1: 2000)$ for $1 \mathrm{~h}$. The blot was washed again with PBS/Tween and developed with horseradish peroxidase (HRP)coupled goat anti-rabbit $(1: 2000 ;$ DAKO) followed by enhanced chemiluminescence (Amersham Intl., UK).

\section{Determination of CD95 expression}

Following detachment of the cells with RPMI/EDTA, cytofluorimetric analysis of CD95 was performed with CD95 mouse monoclonal IgG antibody DX2 $(1 \mu \mathrm{g} / \mathrm{ml}){ }^{54}$ To determine CD95 protein levels, extracts 
from breast tumor cells were prepared as described above and CD95 was detected with a CD95 rabbit polyclonal $\mathrm{lgG}$ antibody $(0.2 \mu \mathrm{g} / \mathrm{ml})$ (C-20, Santa Cruz). CD95 mRNA expression was determined by Northern blot analysis using the $0.7 \mathrm{~kb}$ Xhol-BamHI DNA fragment of the pBLF58-1 plasmid $^{7}$ as a probe. The probe was labeled with ${ }^{32} \mathrm{P}$ by the random primer procedure.

\section{Analysis of the expression of p53, WAF1/p21 and MDM2 proteins}

Proteins were detected by Western blot analysis with anti-p53 sheep polyclonal IgG antibody (1:2500) (Oncogene Research Products, Cambridge, MA, USA), anti-WAF1/p21 rabbit polyclonal IgG antibody $(0.1 \mu \mathrm{g} / \mathrm{ml})$ (Santa Cruz) and anti-MDM2 mouse monoclonal IgG1 antibody $(0.5 \mu \mathrm{g} / \mathrm{ml})$ (Santa Cruz).

\section{Immunoblot detection of Fas ligand}

Acetone-precipitated proteins from cell lysates were resolved in $10 \%$ SDS-PAGE minigels. Blots were probed with rabbit polyclonal antiFasL Ab $(0.1 \mu \mathrm{g} / \mathrm{ml})(\mathrm{Q}-20$, Santa Cruz).

\section{Generation of stable transfectants of MCF-7}

Stable cell lines expressing the human papillomavirus type 16 E6 protein ${ }^{26}$ were generated by electroporation of MCF-7 cells with $10 \mu \mathrm{g}$ of either pCMV-neo or pCMV16-E6 DNA and selection in culture medium with $2 \mathrm{mg} / \mathrm{ml} \mathrm{G} 418$ sulfate (Sigma Chemical Co.). Resistant clones were analyzed for their failure to accumulate p53 upon DNA damage.

To generate breast tumor cells expressing temperature-sensitive p53, MCF-7 cells were cotransfected by electroporation with the plasmid pBabe-puro $(2 \mu \mathrm{g})$ which confers resistance to puromycin and $10 \mu \mathrm{g}$ of either the empty vector or pLTRcGp53(Val135). ${ }^{27}$ Resistant clones were selected in $1 \mu \mathrm{g} / \mathrm{ml}$ puromycin (Sigma) and analyzed for p53 expression by Western blot.

\section{Acknowledgements}

This work was supported by a grant from the Fundación Ramón Areces to ALR. M.C.R-R was supported by fellowships from the Fundación Científica de la Asociación Española Contra el Cáncer and the Fundación Ramón Areces. We would like to thank Dr. M. Ruiz de Almodovar, and Dr. M.T. Valenzuela (Department of Radiology, University of Granada) for kindly providing the breast tumor cell lines used in this work and for their help in the $\gamma$-irradiation experiments. We would like to acknowledge Dr. A. Weiss and Genentech, Inc. (South San Francisco, CA, USA) for providing the J-HM1-2.2 cell line (material transfer agreement No. 6009-121033). We are grateful to Dr. Moshe Oren (Weizmann Institute, Rehovot, Israel), Dr. Kathleen R. Cho (Johns Hopkins School of Medicine, Baltimore, USA) and Dr. Shigekazu Nagata (Osaka University Medical School, Osaka, Japan) for providing pLTRcGp53(Val135), pCMV16-E6 and pBLF58-1 plasmids, respectively. We thank $C$. Muñoz-Pinedo and M. Sarker for comments on the manuscript. Gema Robledo is acknowledged for expert technical assistance.

\section{References}

1. Barry MA, Behnke CA and Eastman A (1990) Activation of programmed cell death (apoptosis) by cisplatin, other anticancer drugs, toxins and hyperthermia. Biochem. Pharmacol. 40: 2353-2362
2. El-Deiry WS, Tokino T, Velculescu VE, Levy DB, Parsons R, Trent JM, Lin D, Mercer E, Kinzler KW and Vogelstein B (1993) WAF1, a potential mediator of p53 tumor suppression. Cell 75: 817-825

3. Lowe SW, Schmitt EM, Smith SW, Osborne BA and Jacks T (1993) p53 is required for radiation-induced apoptosis in mouse thymocytes. Nature 362 : 847-849

4. Clarke AR, Purdie CA, Harrison DJ, Morris RG, Bird CC, Hooper ML and Wyllie (1993) Thymocyte apoptosis induced by p53-dependent and independent pathways. Nature 362: 849-852

5. Friesen C, Herr I, Krammer PH and Debatin KM (1996) Involvement of the CD95 (APO-1/Fas) receptor/ligand system in drug-induced apoptosis in leukemia cells. Nature Medicine 2: 574-577

6. Müller M, Strand S, Hug H, Heinemann E-M, Walczak H, Hofmann WJ, Stremmel W, Krammer PH and Galle PR (1997) Drug-induced apoptosis in hepatoma cells is mediated by the CD95 (APO-1/Fas) receptor/ligand system and involves ativation of wild-type p53. J. Clin. Inves. 99: 403-413

7. Itoh N, Yonehara S, Ishii A, Yonehara M, Mizushima SI, Sameshima M, Hase A, Seto Y and Nagata S (1991) The polypeptide encoded by the cDNA for humancell surface antigen Fas can mediate apoptosis. Cell 66: 233-243

8. Oehm A, Behrmann I, Falk W, Pawlita M, Maier G, Klas C, Li-Weber M, Richards S, Dhein J, Trauth BC, Ponstingl H and Krammer PH (1992) Purification and molecular cloning of the APO-1 antigen, a new member of the TNF/NGF receptor superfamily: sequence identity with the Fas antigen. J. Biol. Chem. 267: 1070910715

9. Suda T, Takahashi T, Golstein P and Nagata S (1993) Molecular cloning and expression of the Fas ligand, a novel member of the tumor necrosis factor family. Cell 75: $1169-1178$

10. Tanaka M, Suda T, Takahashi T and Nagata S (1995) Expression of the functional soluble form of human Fas ligand in activated lymphocytes. EMBO J.14: $1129-1135$

11. Nagata S and Suda T (1995) Fas and Fas ligand: Iprand gldmutations. Immunol. Today 16: 39-43

12. Fisher GH, Rosenberg FJ, Straus SE, Dale JK, Middleton LA, Lin AY, Strober W, Lenardo MJ and Puck JM (1995) Dominat interfering Fas gene mutations impair apoptosis in a human autoimmune lymphoproliferative syndrome. Cell 81:935946

13. Leithauser F, Dhein J, Mechtersheimer G, Koretz K, Bruderlein S, Henne C, Schmidt A, Debatin KM, Krammer PH and Moller P (1993) Constitutive and induced expression of APO-1, a new member of the nerve growth factor/tumor necrosis factor receptor superfamily, in normal and neoplastic cells. Lab. Invest. 69: $415-429$

14. Keane MM, Ettenberg SA, Lowrey GA, Russell EK and Lipkowitz S (1996) Fas expression and function in normal and malignant breast cell lines. Cancer Res. 56: $4791-4798$

15. Mizutani Y, Okada Y, Yoshida O, Fukumoto M and Bonavida B (1997) Doxorubicin sensitizes human bladder carcinoma cells to Fas-mediated cytotoxicity. Cancer 79: 1180-1189

16. Roth W, Fontana A, Trepel M, Reed JC, Dichgans J and Weller M (1997) Immunochemotherapy of malignant glioma: synergistic activity of CD95 ligand and chemotherapeutics. Cancer Immunol. Immunother. 44: 55-63

17. Sheard MA, Vojtesek B, Janakova L, Kovarik J and Zaloudik J (1997) Upregulation of Fas (CD95) in human p53 wild-type cancer cells treated with ionizing radiation. Int. J. Cancer 73: 757-762

18. Owen-Schaub LB, Zhang W, Cusack JC, Angelo LS, Santee SM, Fujiwara T, Roth JA, Deisseroth AB, Zhang W-W, Kruzel E and Radinsky R (1995) Wild-type human $\mathrm{p} 53$ and a temperature-sensitive mutant induce Fas/APO-1 expression. Mol. Cell. Biol. 15: 3032-3040

19. Jänicke RU, Sprengart ML, Wati MR and Porter AG (1998)Caspase-3 is required for DNA fragmentation and morphological changes associated with apoptosis. J. Biol. Chem. 273: 9357-9360

20. Hirata H, Takahashi A, Kobayashi S, Yonehara S, Sawai H, Okazaki T, Yamamoto K and Sasada M (1998) Caspases are activated in a branched protease cascade and control distinct downstream processes in Fas-induced apoptosis. J. Exp. Med. 187: 587-600

21. Levine AJ (1997) p53, the cellular gatekeeper for growth and division. Cell 88: $323-331$

22. Steinman RA, Hoffman B, Iro A, Guillouf C, Liebermann DA and El-Houseini ME (1994) Induction of p21 (WAF-1/CIP1) during differentiation. Oncogene 9 : $3389-3396$ 
23. Piette J, Neel H and Maréchal V (1997) Mdm2: keeping p53 under contro Oncogene 15: 1001-1010

24. Haupt Y, Maya R, Kazaz A and Oren M (1997) Mdm2 promotes the rapid degradation of p53. Nature 387: 296-299

25. Hollstein M, Rice K, Greenblatt MS, Soussi T, Fuchs R, Sorlie T, Hovig E, SmithSorensen B, Montesano R and Harris CC (1994) Database of p53 gene somatic mutations in human tumors and cell lines. Nucleic Acids Res. 22: 3551-3555

26. Kessis TD, Slebos RJ, Nelson WG, Kastan MB, Plunkett BS, Han SM, Lorincz AT, Hedrick L and Cho KR (1998) Human papillomavirus 16 E6 expression disrupts the p53-mediated cellular response to DNA damage. Proc. Natl. Acad. Sci. USA 90: 3988-3992

27. Michalovitz D, Halevy $O$ and Oren M (1990) Conditional inhibition of transformation and of cell proliferation by a temperature-sensitive mutant of p53. Cell 62: $671-680$

28. Michael-Michalovitz D, Yehiely F and Oren M (1991) Simian virus 40 can overcome the antiproliferative effect of wild-type p53 in the absence of stable large T antigen-p53 binding. J. Virol. 65: 4160-4168

29. Friedman SL, Shaulian E, Littlewood T, Resnitzky D and Oren M (1997) Resistance to p53-mediated growth arrest and apoptosis in Hep 3B hepatoma cells. Oncogene 15: 63-70

30. Chirillo P, Pagano S, Natoli G, Puri PL, Burgio VL, Balsano C and Levrero M (1997) The hepatitis B virus $X$ gene induces p53-mediated programmed cell death. Proc. Natl. Acad. Sci. USA 94: 8162-8167

31. Strand S, Hofmann WJ, Hug H, Müller M, Otto G, StrandD, Mariani SM, Stremme W, Krammer PH and Galle PR (1996) Lymphocyte apoptosis induced by CD95 (APO-1/Fas) ligand-expressing tumor cells - A mechanism of immune evasion? Nature Medicine 2: 1362-1366

32. Herr I, Wilhelm D, Böhler T, Angel P and Debatin K-M (1997) Activation of CD95(APO-1/Fas) signaling by ceramide mediates cancer therapy-induced apoptosis. EMBO J. 16: 6200-6208

33. Faris M, Kokot N, Latinis K, Kasibhatla S, Green DR, Koretzky GA and Nel A (1998) The c-Jun N-terminal kinase cascade plays a role in stress-induced apoptosis in Jurkat cells by up-regulating Fas ligand expresison. J. Immunol. 160: $134-144$

34. Izquierdo M, Ruiz-Ruiz MC and Lopez-Rivas A (1996) Stimulation of phosphatidylinositol turnover is a key event for Fas-dependent, activationinduced apoptosis in human T lymphocytes. J. Immunol. 157: $21-28$

35. Winthrop MD, DeNardo SJ, Muenzer JT, Chi SG and Gumerlock PH (1997) p53 independent response of a human breast carcinoma xenograft to radioimmunotherapy. Cancer 80: 2529-2537

36. Strasser A, Harris AW, Jacks T and Cory S (1994) DNA damage can induce apoptosis in proliferating lymphoid cells via p53-independent mechanisms inhibitable by Bcl-2. Cell 79: 329-339

37. Gartenhaus RB, Wang P and Hoffmann P (1996) Induction of the WAF1/CIP1 protein and apoptosis in human T-cell leukemia virus type I-transformed lymphocytes after treatment with adriamycin by using a p53-indepenent pathway. Proc. Natl. Acad. Sci. USA 93: 265-268

38. Woo M, Haken R, Soengas MS, Duncan GS, Shahinian A, Kägi D, Hakem A, McCurrach M, Khoo W, Kaufman SA, Senaldi G, Howard T, Lowe SW and Mak TW (1998) Essential contribution of caspase3/CPP32 to apoptosis and its associated nuclear changes. Genes and Dev. 12: 806-819
39. Droin N, Dubrez L, Eymin B, Renvoizé C, Bréard J, Dimanche-Boitrel MT and Solary $E$ (1998) Upregulation of CASP genes in human tumor cells undergoing etoposide induced apoptosis. Oncogene 16: 2885-2894

40. Ossina NK, Cannas A, Powers VC, Fitzpatrick PA, Knight JD, Gilbert JR, Shekhtman EM, Tomei LD, Umansky SR and Kiefer MC (1997) Interferon- $\gamma$ moduilates a p53-independent apoptotic pathway and apoptosis-related gene expression. J. Biol. Chem. 272: 16351-16357

41. Tamura T, Ishihara M, Lamphier MS, Tanaka N, Oishi I, Aizawa S, Matsuyama T, Mak TW, Taki S and Taniguchi T (1998) An IRF-1-dependent pathway of DNA damage-induced apoptosis in mitogen-activated T lymphocytes. Nature 376 : 596-599

42. Schiltz PM, Beutel LD, Nayak SK and Dillman RO (1997) Characterization of tumor-infiltrating lymphocytes derived from human tumors for use as adoptive immunotherapy of cancer. J. Immunother. 20: 377-386

43. Tamura T, Aoyama N, Saya H, Haga H, Futami S, Miyamoto S, Koh T, Ariyasu T, Tachi M, Kasuga Mand Takahashi R(1995) Induction ofFas-mediated apoptosis in p53-transfected human colon carcinoma cells. Oncogene 11: 1939-1946

44. Silvestrini R, Benini E, Veneroni S, Daidone MG, Tomasic G, Squicciarini P and Salvadori B (1996) p53 and bcl-2 expression correlates with clinical outcome in a series of node-positive breast cancer patients. J. Clin. Oncol. 14: 1604-1610

45. Silvestrini R, Benini E, Daidone MG, Veneroni S, Boracchi P, Cappelletti V, Di Fronzo G and Veronesi U (1993) p53 as an independent prognostic marker in lymph node-negative breast cancer patients. J. Natl. Cancer Inst. 85: 965-970

46. Dublin EA, Miles DW, Rubens RD, Smith P and Barnes DM (1997) p53 immunohistochemical staining and survival after adjuvant chemotherapy for breast cancer. Int. J. Cancer 74: 605-608

47. El-Deiry WS, Kern SE, Pietenpol JA, Kinzler KW and Vogelstein B (1992) Definition of a consensus binding site for p53. Nat. Genet. 1: 45-49

48. Miyashita Tand Reed JC (1995) Tumor suppressor $\mathrm{p} 53$ is a direct transcriptional activator of the human bax gene. Cell 80: 293-299

49. Ludwig RL, Bates S and Vousden KH (1996) Differential activation of target cellular promoters by $\mathrm{p} 53$ mutants with impaired apoptotic function. Mol. Cell Biol. 16: 4952-4960

50. Behrmann I, Walczak H and Krammer PH (1994) Structure of the human APO-1 gene. Eur. J. Immunol. 24: 3057-3062

51. Cheng J, Liu C, Koopman WJ and Mountz JD (1995) Characterization of human Fas gene. Exon/intron organization and promoter region. J. Immunol. 154: $1239-1245$

52. Sánchez A, Alvarez AM, Benito M and Fabregat I (1996) Apoptosis induced by transforming growth factor- $\beta$ in fetal hepatocyte primary cultures. J. Biol. Chem. 271: $7416-7422$

53. Gong J, Traganos F and Darzynkiewicz Z (1994) A selective procedure for DNA extraction from apoptotic cells applicable for gel electrophoresis and flow cytometry. Anal. Biochem. 218: 314-319

54. Ruiz-Ruiz MC, Izquierdo M, de Murcia G and López-Rivas A (1997) Activation of protein kinase $\mathrm{C}$ attenuates early signals in Fas-mediated apoptosis. Eur. J. Immunol. 27: 1442-1450 